\title{
Effectiveness of application of lignolytic fungal strains, Cladosporium uredinicola GRDBF21 and Bipolaris maydis GRDBF23 in the treatment of tannery effluent
}

Paper received: 02.11.2017

Revised received: 26.02 .2018

Re-revised received: 07.05.2018

Accepted: 10.07.2018

\section{Authors Info \\ J.T. Joseph', R. Mahalakshmi ${ }^{19}, \mathrm{~K}$. Revathy', K. Panneerselvam², P. Manikandan $^{3,4}$ and C.S. Shobana ${ }^{5 *}$ 'Department of Microbiology, Dr. G.R. Damodaran College of Science, Coimbatore - 641 014, India \\ ${ }^{1 a}$ Department of Biotechnology, Dr. G.R. Damodaran College of Science, Coimbatore - 641 014, India ${ }^{2}$ Department of Microbiology, MR Government Arts College, Mannargudi - 614 014, India \\ ${ }^{3}$ Aravind Eye Hospital and Postgraduate Institute of Ophthalmology, Coimbatore, Tamilnadu- 641 014, India \\ ${ }^{4}$ Department of Medical Laboratory Sciences, College of Applied Medical Sciences, Majmaah University, Kingdom of Saudi Arabia - 11952 \\ ${ }^{5}$ Department of Microbiology, PSG College of Arts \& Science, Coimbatore - 641 014, India}

*Corresponding Author Email : shobanasenthilkumar@gmail.com

\section{Edited by \\ Dr. G. Poyyamoli}

Reviewed by Dr. Bhim Pratap Singh Dr. R. B. Raizada

\section{Abstract}

Aim : This study aims to investigate the ability of laccase producing fungal strains Cladosporium uredinicola GRDBF21 and Bipolaris maydis GRDBF23 isolated from decaying wood bark in decolouration and detoxification of tannery effluent.

Methodology : Fungal strains from decaying wood bark samples were isolated by serial dilution technique followed by single spore isolation method. The selected fungal isolates were investigated for their laccase enzyme production. Their effect on physio-chemical properties of tannery effluent collected from final effluent drainage of a leather-tanning factory in Chrompet, Chennai, Tamil Nadu, India was analysed. Toxicity of treated and untreated tannery effluent was analysed by seed germination test.

Results : The lignolytic and constitutive producers of laccase enzyme, $C$. uredinicola GRDBF21 and $B$. maydis GRDBF23 exhibited a tolerance index of 1.2 and 1.5 , respectively, at $60 \%$ effluent concentration. The isolates were able to increase $\mathrm{pH}$ and reduce colour, turbidity, total suspended solids and electrical conductivity of the effluent. Besides observing a decrease in the BOD and COD levels, there was also a reduction in the sodium and hexavalent chromium content. C. uredinicola GRDBF21 and B. maydis GRDBF23 treated effluent showed a seed germination percentage of $66.6 \%$ and $76.6 \%$, respectively. The untreated effluent completely inhibited the seed germination.

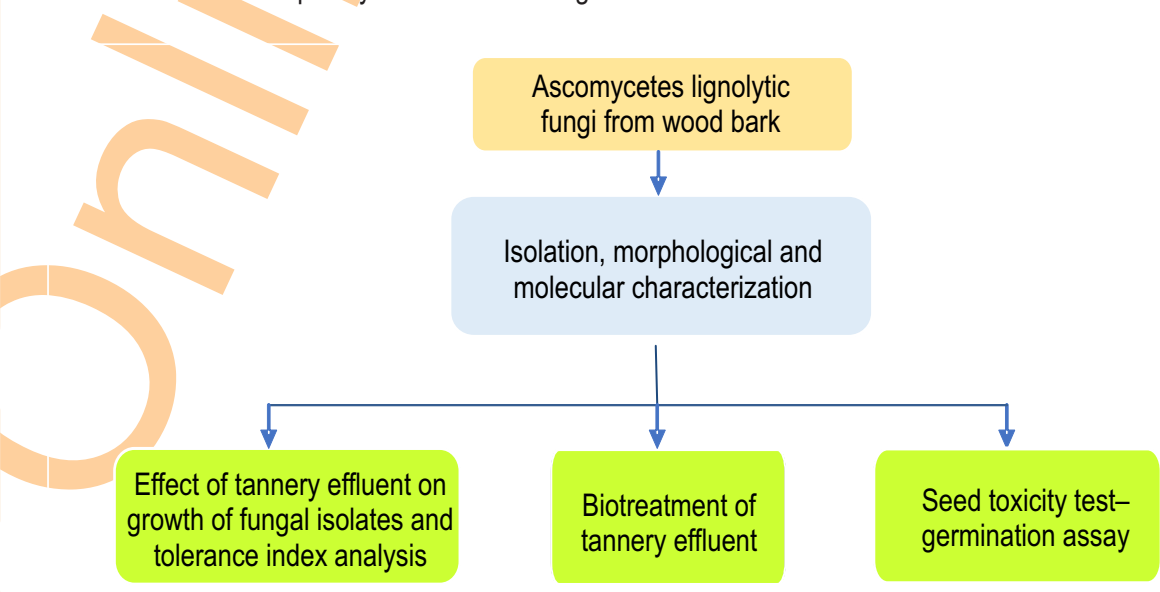

Interpretation : The study confirms that the fungal species C. uredinicola GRDBF21 and B. maydis GRDBF23 could be effectively used in decolouration and detoxification of tannery effluent.

Key words: Ascomycetes fungi, Bioremediation, Laccase, Lignolytic enzymes, Tannery effluent

Citation: Joseph, J.T., R. Mahalakshmi, K. Revathy, K. Panneerselvam, P. Manikandan and C.S. Shobana: Effectiveness of application of lignolytic fungal strains, Cladosporium uredinicola GRDBF21 and Bipolaris maydis GRDBF23 in the treatment of tannery effluent. J. Environ. Biol., 40, 158-164(2019). 


\section{Introduction}

Tannery industries hold a major sector in the economy of many countries and are considered as an inevitable part of leather manufacturing (Hasegawa et al., 2011). Tanning process converts the animal skin into useful leather material by altering the protein of rawhide into a flexible and stable material, which will not putrefy and is suitable for a wide variety of end applications. This complex process uses chemicals such as chromium, sulfides, ammonium, acids and different types of organic and inorganic ingredients. Majority of chemical compounds used for tanning, post tanning and dyeing process are toxic and recalcitrant compounds (Jnr and Spiff, 2005; Kongjao et al., 2008; Abdallh et al., 2016; Chowdhury et al., 2015)).

Physico-chemical methods like recycling, coagulation, membrane filtration, reverse osmosis and adsorption are used for the treatment and detoxification of tannery effluents. These methods are not considered as a sustainable remedy for the effluent pollution problem, because of the transfer of contaminants takes place from one phase to another (Hasegawa et al., 2011). Bioremediation of toxic industrial effluents using microorganisms is considered as an efficient method to replace the conventional treatment methods. Ascomycetes are efficient in degrading a large variety of dyes, phenolic and non-phenolic compounds, demonstrating a high potential for environmental bioremediation. Many fungi have the ability to biosorb and bioaccumulate metals and are involved in the reduction of hexavalent chromium to trivalent chromium (Arévalo-Rangel et al., 2013). Fungal/microbial treatment methods for decolourisation and detoxification of industrial effluents have been reported earlier (Sharma and Malaviya, 2014; Choi et al., 2014; Hossain and Ismail, 2015; Hossain et al., 2016). Lignolytic fungi produce a special group of enzymes such as lignin peroxidase, manganese peroxidase and laccases, which are involved in the degradation and break down of complex aromatic polymers such as lignin and structurally complex toxic environmental pollutants (BonugliSantos et al., 2012). Ascomycetes are known producers of laccase enzyme (Brijwani, 2010). Lignolytic fungi and their enzymatic system are involved in the degradation of xenobiotic compounds, dyes and treatment of various industrial effluents (Ravikumar et al., 2011; Hasegawa et al., 2011). Laccase enzyme is being widely used for the degradation and removal of various aromatic compounds and pollutants in industrial waste, contaminated water and soil (Madhavi and Lele, 2009). Several studies have reported the potential use of lignolytic fungi for bioremediation of various industrial effluents like tannery, textile, pulp and paper industry (Gómez-Bertel et al., 2008; Anastasi et al., 2010; Chopra and Singh, 2012; Kunjadia et al., 2016). Against this background, the present study was undertaken to analyze the effect of laccase producing fungi isolated from tree barks for decolouration and detoxification of tannery effluent.

\section{Materials and Methods}

Sampling and isolation of fungi : Eighteen bark samples from trees and decaying woods of Painavu forest $\left(9.7824^{\circ} \mathrm{N}, 76.9643^{\circ} \mathrm{E}\right)$ in Kerala were collected. One $\mathrm{cm}$ cubic sections of these barks were collected in sterile polythene and were transferred to laboratory. The collected bark samples were incubated in $100 \mathrm{ml}$ sterile Sabouraud dextrose broth at $25^{\circ} \mathrm{C}$ for 7 days. The experiments were carried out in duplicates. Subsequently, the broth was serially diluted and plated on Sabouraud dextrose agar and incubated at $25^{\circ} \mathrm{C}$ for 5-7 days. Further, purification of isolates was done by single spore culture method (Ko et al., 2001). The fungal isolates were stored as a small agar block from the pure culture in sterile $0.85 \%$ saline solution at $27^{\circ} \mathrm{C}$. The axenic cultures were grown in malt extract agar plates until profuse sporulation was obtained and mycelial discs from these plates were used as inoculum for further studies.

Laccase screening : The fungal isolates were grown on laccase detection medium containing 2, 2'-azino-bis (3ethylbenzthiazoline-6-sulfonic acid) (ABTS) at $28^{\circ} \mathrm{C}$ for $3-5$ days, and the plates were observed for dark green colouration around the colony which suggested laccase enzyme production (Jin et al., 2012). For the assay of laccase enzyme, fungal agar disc of 5 $\mathrm{cm}$ was placed in modified Tien and Kirk's broth medium (Mabrouk et al., 2010). After 15 days of incubation at $28^{\circ} \mathrm{C}, 5 \mathrm{ml}$ of broth was centrifuged (Plastocrafts, Model superspin R-V/FM) at $4^{\circ} \mathrm{C}$ for $10 \mathrm{~min}$ at $10,000 \mathrm{rpm}$. The supernatant was collected and used as enzyme source for the assay procedures (Bourbonnais et al., 1995). One unit of laccase activity was defined as activity of an enzyme that catalyzes the conversion of one mole of ABTS $\left(E_{420}=36,000 \mathrm{M}^{-1} \mathrm{~cm}^{-1}\right) \mathrm{min}^{-1}$.

Identification of fungal isolates : The test mycelial discs $(1 \mathrm{~cm})$ were inoculated at the center of SDA and incubated at $28^{\circ} \mathrm{C}$ for 5-7 days. After incubation, the appearance, texture and colour of the colonies were observed. The microscopic observation of fungal isolates was done after lacto-phenol cotton blue staining.

The DNA extraction from fungal cultures were carried out using NucleoSpin® Plant II genomic kit following manufacturer's instructions and were assessed for their purity on an agarose gel before they were subjected to amplification by polymerase chain reaction. The 28S ribosomal RNA gene (partial sequence) incorporating D1/D2/D3 regions of the fungal DNA samples were amplified using the following LSU primer sets: Forward primer: UL18F: 5' - TGTACACACCGCCCGTC- 3'; Reverse primer: UL28R: 5'- ATCGCCAGTTCTGCTTAC -3'. Sequencing of LSU 28S rRNA gene was performed commercially at ProGen Life Science Solutions (Salem, Tamil Nadu, India). For the analysis of sequenograms, the following software was used: Chromas Lite (Technelysium Pty. Ltd.), BioEdit, ClustalX 2.0.11 and the findings were critically evaluated (Hall, 1999; Higgins et al., 1996). DNA sequences representing LSU $28 S$ ribosomal RNA gene was compared with similar sequences available in the National Centre for Biotechnology Information (NCBI) and was submitted to GenBank.

Characterization of tannery effluent : Tannery effluent samples were collected in sterile plastic containers from the final effluent drainage of a leather tanning industry located at Chrompet, 
Chennai, Tamil Nadu, India. The samples were transferred to laboratory within 24 hours for further processing. The effluent samples were stored at $4^{\circ} \mathrm{C}$ until further use. For broth studies, 250 $\mathrm{ml}$ of sterile tannery effluent $(100 \%)$ amended with $2 \%(\mathrm{w} / \mathrm{v})$ malt extract was inoculated with $5 \mathrm{~cm}$ mycelial disc of test fungal isolates and incubated at $28^{\circ} \mathrm{C}$ for 10 days on a rotary orbital shaker (REMI, Model RIS-24). The analysis of physico-chemical characteristics, such as $\mathrm{pH}$, colour, chemical oxygen demand (COD), biochemical oxygen demand (BOD), total suspended solids (TSS), electrical conductivity (EC), levels of hexavalent chromium and sodium of biologically treated and untreated tannery effluent were performed using the standard methods of APHA (2012). The pH was determined using digital pH meter (EUTECH pH 510). Colour was checked using spectrophotometer (Merck, Spectroquant Pharo 100). Turbidity was measured in a turbidimeter (Merck, Model Pharo100). COD and BOD were determined by open reflux titrimetric method and Winkler's iodometric method, respectively. TSS was determined by filtration method. Hexavalent chromium and sodium concentration were determined by atomic absorption spectrometry (Shimadzu, Model AA-7000) and flame photometery (ELICO CL378 flame photometer), respectively.

To analyze the tolerance of fungal isolates towards tannery effluent, radial growth of fungi was estimated on MEA amended with $0 \%, 30 \%, 60 \%$ and $100 \%$ of tannery effluent and incubated at $28^{\circ} \mathrm{C}$ for 8 days. After incubation, mean radial growth diameter $(\mathrm{cm})$ was measured and mean tolerance index (TI) was calculated. Seed germination test was performed for toxicity testing of treated and untreated tannery effluent (Ahsan et al., 2007). Sterile Whatman No.1 filter paper was placed in the Petri dishes and was appropriately moistened with $10 \mathrm{ml}$ of treated and untreated tannery effluent. Filter paper moistened with tap water served as control. Mung bean (Vigna radiata) seeds were surface sterilized with $8 \%$ sodium hypochlorite $(\mathrm{NaClO})$ for 10 min and washed three times with sterile distilled water. A total of 10 seeds were placed in the moistened filter paper and plates were incubated at $27^{\circ} \mathrm{C}$ in dark with $50 \%$ air humidity. Each set of experiment was conducted in triplicate and the mean value was taken. Visible protrusion of radicle from seed coat was considered as criterion of seed germination and mean germination rate was calculated.

\section{Results and Discussion}

A total of 28 fungal isolates, i.e., Aspergillus spp. $(n=6)$, Fusarium spp. (n=8), Rhizopus spp. $(\mathrm{n}=5)$, Cladosporium spp. $(n=4)$, Bipolaris spp. $(n=3)$ and Alternaria spp. $(n=2)$ were isolated from bark samples. Among these isolates, only two were positive for laccase production and they were identified as Cladosporium $\mathrm{sp}$. and Bipolaris sp. based on the colony morphology and microscopic characteristics. Laccase assay revealed that these isolates, i.e., Cladosporium sp. GRDBF21 and Bipolaris sp. GRDBF23 had the mean laccase activity of $193.75 \mathrm{Ul}^{-1}\left(11^{\text {th }}\right.$ day of incubation) and $334.0 \mathrm{Ul}^{-1}$ ( $9^{\text {th }}$ day of incubation), respectively. Upon molecular characterization by the sequencing of LSU $28 \mathrm{~S}$ ribosomal RNA gene, these isolates were identified as Cladosporium uredinicola GRDBF21 (GenBank accession number: KJ913698) and Bipolaris maydis GRDBF23 (GenBank accession number: KJ913699). C. uredinicola GRDBF21 and $B$. maydis GRDBF23 belong to the Phylum Ascomycota which comprise of members with effective lignolytic activity. TapiaTussell et al. (2011) reported that Bipolaris spp. isolated from wood decay was able to exhibit only $7.50 \mathrm{UI}^{-1}$ of laccase activity. Laccase producing $C$. cladosporioides was reported with a maximum laccase activity of $190 \mathrm{U} \mathrm{ml}^{-1}$ (Aslam et al., 2012). Jin et al. (2012) stated that $C$. cladosporioides isolated from soil was able to show a laccase activity of $241 \mathrm{U} \mathrm{I}^{-1}$. Laccase producing psychrotolerant $C$. tenuissimum from cold desert in Indian Himalayas has also been reported with a laccase activity of 15.10 $\mathrm{UI}^{-1}$ (Dhakar and Pandey, 2016).

The study revealed that the colour of untreated effluent was black and the odour was much offensive. But after the treatment with the test fungal isolates, the colour of the effluent diminished to light yellow and also the effluent reached to an odourless state. The colour intensity of $C$. uredinicola GRDBF21 and $B$. maydis GRDBF23 treated effluents dropped to less than 8000 and 5000 , respectively, against untreated effluent colour intensity of 15225 (Table1). This may be attributed to higher production of laccase enzyme by the isolate. A white rot fungus, Trametes versicolor was able to remove $86-89 \%$ of tannery dye, black dycem (Baccar et al., 2011). Various lignolytic and other

Table 1 : Physico-chemical characteristics of untreated and treated effluent from leather tanning industry in Chennai

\begin{tabular}{|c|c|c|c|}
\hline \multirow{2}{*}{ Parameters } & \multirow{2}{*}{$\begin{array}{l}\text { Untreated } \\
\text { effluent }^{\phi}\end{array}$} & \multicolumn{2}{|c|}{ Treated effluent $^{\phi}$} \\
\hline & & $\begin{array}{l}\text { Cladosporium } \\
\text { uredinicola GRDBF21 }\end{array}$ & $\begin{array}{l}\text { Bipolaris } \\
\text { maydis GRDBF23 }\end{array}$ \\
\hline $\mathrm{pH}$ & 4.45 & 6.10 & 6.02 \\
\hline Colour & 15225 & $<8000$ & $<5000$ \\
\hline Turbidity & 6750 & $<10$ & $<15$ \\
\hline $\mathrm{BOD}\left(\mathrm{mg} \mathrm{l}^{-1}\right)$ & 3120 & 2950 & 3100 \\
\hline $\operatorname{COD}\left(\mathrm{mg} \mathrm{l}^{-1}\right)$ & 11180 & 11100 & 10100 \\
\hline Total suspended solids ( $\mathrm{mg} \mathrm{l}^{-1}$ ) & 4232 & 113 & 104 \\
\hline Electrical conductivity ( $\mu$ mhos $\left.\mathrm{cm}^{-1}\right)$ & 19000 & 12620 & 12410 \\
\hline Hexavalent chromium ( $\left.\mathrm{mg} \mathrm{l}^{-1}\right)$ & 0.28 & 0.011 & 0.022 \\
\hline Sodium $\left(\mathrm{mg} \mathrm{l}^{-1}\right)$ & 3465 & 1235 & 1432 \\
\hline
\end{tabular}

\footnotetext{
${ }^{\phi}$ Values are mean of duplicate determinations
} 
Table 2 : Effect of tannery effluent from leather tannery in Chennai on the growth of fungal isolates by plate assay

\begin{tabular}{|c|c|c|c|c|c|}
\hline \multirow{2}{*}{ Fungal isolates } & \multirow{2}{*}{$\begin{array}{l}\text { Effluent } \\
\text { concentration } \\
(\%)\end{array}$} & \multicolumn{3}{|c|}{ Mean ${ }^{\epsilon}$ radial growth diameter $(\mathrm{cm})$} & \multirow{2}{*}{$\begin{array}{l}\text { Tolerance } \\
\text { index }\end{array}$} \\
\hline & & Day 2 & Day 6 & Day 8 & \\
\hline $\begin{array}{l}\text { Cladosporium } \\
\text { uredinicola GRDBF21 }\end{array}$ & $\begin{array}{l}0 \\
30 \\
60 \\
100\end{array}$ & $\begin{array}{l}0.5 \\
0.8 \\
1 \\
0.8\end{array}$ & $\begin{array}{l}1.8 \\
2.4 \\
2.6 \\
2\end{array}$ & $\begin{array}{l}2.5 \\
2.8 \\
3 \\
2.5\end{array}$ & $\begin{array}{l}-- \\
1.12 \\
1.2 \\
1\end{array}$ \\
\hline $\begin{array}{l}\text { Bipolaris maydis } \\
\text { GRDBF23 }\end{array}$ & $\begin{array}{l}0 \\
30 \\
60 \\
100\end{array}$ & $\begin{array}{l}0.8 \\
0.5 \\
1.3 \\
0.9\end{array}$ & $\begin{array}{l}2.3 \\
2.7 \\
3.3 \\
2.5\end{array}$ & $\begin{array}{l}2.8 \\
3.8 \\
4.2 \\
3.2\end{array}$ & $\begin{array}{l}-- \\
1.35 \\
1.5 \\
1.14\end{array}$ \\
\hline
\end{tabular}

${ }^{\epsilon}$ Values are mean of triplicate determinations

fungal species i.e., Phanerochaete sp., Trametes sp., Cladosporium sp., Pleurotus sp., Aspergillus sp., and Ganoderma sp., have shown their ability to remove colour from various industrial and wastewater effluents (Srikanlayanukul et al., 2006; Tehrani et al., 2015; Ravikumar et al., 2011).

The $\mathrm{pH}$ of untreated tannery effluent was found to be 4.45. Discharge of untreated tannery effluents with low $\mathrm{pH}$ to nearby water bodies and soil may be detrimental to aquatic and soil system. C. uredinicola GRDBF21 and B. maydis GRDBF23 effectively increased the $\mathrm{pH}$ of tannery effluent to 6.10 and 6.02 , respectively, from an acidic to almost neutral $\mathrm{pH}$ range (Table 1). Turbidity of untreated effluent was 6750 . After treatment with $C$. uredinicola GRDBF21 and $B$. maydis GRDBF23, the turbidity was reduced to $<10$ and $<15 \mathrm{NTU}$, respectively. This indicates that the lignolytic fungi grown in tannery effluent had either used or degraded the molecules causing turbidity. Similar to the present study, Sharma and Malaviya (2016) stated that Aspergillus flavus isolated from a tannery container exhibited $98.02 \%$ reduction in the turbidity of treated tannery effluent.
Tannery wastewater with high BOD and COD is characterized by substantial organic, inorganic matter content and refers to high oxygen demand through biological organisms and chemicals, and thus treatment of tannery effluent poses a major challenge. BOD and COD level of untreated effluent was $3120 \mathrm{mg} \mathrm{l}^{-1}$ and $11180 \mathrm{mg} \mathrm{l}^{-1}$, respectively. Treatment with $C$. uredinicola GRDBF21 and $B$. maydis GRDBF23 brought down the BOD level to 2950 and $3100 \mathrm{mg} \mathrm{l}^{-1}$ and COD level to $11100 \mathrm{mg} \mathrm{l}^{-1}$ and $10100 \mathrm{mg} \mathrm{l}^{-1}$, respectively. In a study, Botryosphaeria rhodina use for treating undiluted crude tannery effluent with high BOD and COD levels couldn't support the fungal growth and was not able to give satisfactory results in the reduction of BOD and COD level (Hasegawa et al., 2011).

TSS level of tannery effluent was $4232 \mathrm{mg} \mathrm{l}^{-1}$, but after treatment with $C$. uredinicola GRDBF21 and $B$. maydis GRDBF23 it was reduced to $113 \mathrm{mg} \mathrm{l}^{-1}$ (\% reduction-97.32\%) and $104 \mathrm{mg} \mathrm{I}^{-1}$ (\% reduction-97.54\%), respectively. These solid impurities may cause turbidity in the receiving water bodies and lead to poor penetration of light in aquatic system. Trametes hirsuta, a white

Table 3 : Effect of untreated and treated effluent from leather tanning industry in Chennai on mung bean (Vigna radiata) seed germination

\begin{tabular}{lll}
\hline Treatment of seeds & No. of seeds germinated ${ }^{ \pm}$ & Mean germination rate (\%) $^{*}$ \\
\hline Tap water & $9.66 \pm 0.577$ & 96.6 \\
Untreated tannery effluent & 0 & 0 \\
$\begin{array}{l}\text { Cladosporium uredinicola } \\
\text { GRDBF21 treated tannery } \\
\text { effluent } \\
\begin{array}{l}\text { Bipolaris maydis GRDBF23 } \\
\text { treated tannery effluent }\end{array}\end{array}$ & $6.66 \pm 0.577$ & 66.6 \\
\end{tabular}

${ }^{7}$ Values are mean \pm SD of triplicate determinations 
rot fungus isolated from decaying wood samples was able to reduce the suspended solids in the industrial effluent and tannery effluent by $41 \%$ and $68 \%$, respectively (Bisht and Harsh, 2014). Reduction in TSS and turbidity is ascribed to entrapment of suspended solid particles by the filamentous fungi (Fakhru'l-Razi and Molla, 2007). The untreated effluent also showed a higher level of electrical conductivity of $19000 \mu \mathrm{mhos} \mathrm{cm}^{-1}$, which reflects high concentration of ions, salts and organic and inorganic substances. The electrical conductivity of the effluent decreased to $12620 \mu$ mhos $\mathrm{cm}^{-1}$ (\% reduction - 33.5) and $12410 \mu \mathrm{mhos} \mathrm{cm}^{-1}$ (\% reduction -34.68$)$ after the treatment with $C$. uredinicola GRDBF21 and B. maydis GRDBF23, respectively. Results show that the performance of both fungi in the reduction of electrical conductivity was almost similar.

The concentration of hexavalent chromium $\left(\mathrm{Cr}^{6+}\right)$ in tannery effluent was $0.28 \mathrm{mgl}^{-1}$ and was reduced to $0.11 \mathrm{mg} \mathrm{l}^{-1}$ and $0.22 \mathrm{mg} \mathrm{l}^{-1}$, after treating with $C$. uredinicola GRDBF21 and $B$. maydis GRDBF23, respectively. The results suggest that both the isolates efficiently removed hexavalent chromium $\left(\mathrm{Cr}^{6+}\right)$ from tannery effluent. Toxic effects and penetration rate of hexavalent chromium to biological membranes are higher when compared to trivalent chromium (El-Kassas and El-Taher, 2009). Many researchers have reported that acidic $\mathrm{pH}$ supports the reduction of hexavalent chromium $\left(\mathrm{Cr}^{6+}\right)$ effectively (Gochev et al., 2010; Shoaib et al., 2013; Saranraj and Sujitha, 2013). These reports justify the findings of the present study using fungi for treating tannery effluent with acidic $\mathrm{pH}$. Microbes assisted technologies provide an alternative or addition to conventional methods of metal removal (Saranraj and Sujitha, 2013). Similar to the present study, the cellular biomass of $C$. neoformans was also able to remove $98 \%$ of chromium (Acosta et al., 2004; Ahluwalia, 2014). It was found that Aspergillus oryzae was able to grow in a chromium concentration of $120-1080 \mathrm{mg} \mathrm{l}^{-1}$ and also removed $94 \%$ of chromium from tannery effluent at $3.3 \mathrm{pH}$ (Igwe and Abia, 2006). In a shake flask culture study, Aspergillus niger and Fusarium chlamydosporium reduced the chromium concentration by 70 and $64.68 \%$ at pH 6 and 5.3, respectively (Srivastava and Thakur, 2006; Sharma and Malaviya, 2014). The living mycelium of Phanerochaete chrysosporium, a widely used lignolytic fungi for bioremediation purposes, has been reported reduce hexavalent chromium in artificial wastewater (Nikazar etal., 2008).

The concentration of sodium in tannery effluent before treatment was $3465 \mathrm{mg} \mathrm{l}^{-1}$ and after treatment with $C$. uredinicola and $B$. maydis reduced to $1235 \mathrm{mg} \mathrm{l}^{-1}(\%$ reduction-64.36) and $1432 \mathrm{mg} \mathrm{I}^{-1}$ (\% reduction-58.68). Two different studies using Fusarium chlamydosporium and Aspergillus flavus for the treatment of tannery effluent showed $11.69 \%$ and $32.79 \%$ reduction in sodium level, respectively (Sharma and Malaviya, 2014, 2016). The tolerance index $(\mathrm{TI})$ of test fungal isolates showed that $C$. uredinicola GRDBF21 and B. maydis GRDBF23 exhibited a maximum $\mathrm{Tl}$ of 1.2 and $1.5 \mathrm{TI}$ at $60 \%$ effluent concentration (Table 2). Tolerance index analysis indicates the growth potential and resistance of fungal isolates at high effluent concentration.
The effluent toxicity test showed that the untreated tannery effluent completely inhibited the process of germination in mung bean seeds. Germination of mung bean seeds treated with tap water as control showed a mean germination rate of $96.6 \%$ whereas C. uredinicola GRDBF21 and B. maydis GRDBF23 treated effluents exhibited a mean germination rate of $66.6 \%$ and $73.3 \%$, respectively (Table 3). Seed germination was completely inhibited in all the mung bean (Vigna radiata) seeds treated with $100 \%$ untreated tannery effluent and none of the green gram seeds germinated even after incubation period. This may be due to the toxicity caused by high BOD, COD, TSS, EC, chromium and acidic nature of the effluent. It is also reported that inhibition of seed germination at higher effluent concentration may be due to high level of solids which enhances salinity and conductivity of solute absorbed by seeds (Sundaramoorthy and Kunjithapatham, 2000). Previous study using Bjerkandera adusta for the reduction of acute toxicity of wastewater by decolourisation is also reported (Choi et al., 2014).

Sharma and Malaviya (2018) reported that an indigenous fungal isolate, Trichoderma viride SPFT1 involved in the decolourisation and detoxification of tannery effluent and the seed germination test exhibited a considerable reduction in the toxicity of fungal treated tannery effluent. According to Noorjahan and Siddiqui (2017), the tannery effluent treated with A. niger and Rhizopus sp. reflected in the increase in seed germination rate. Similar to the present study, Mehta and Bhardwaj (2012) demonstrated the toxic effects of treated and untreated industrial effluents on the seed germination of Vigna radiata (Mung bean) and reported that untreated effluent significantly inhibited the seed germination.

The results of the present study indicates that lignolytic fungal strains, Cladosporium uredinicola GRDBF21 and Bipolaris maydis GRDBF23 isolated from tree bark could be effectively used in decolouration and detoxification of tannery effluent.

\section{Acknowledgments}

The authors thank the management of Dr. G.R. Damodaran College of Science and the Department of Chemistry, South India Textile Research Association (SITRA), Coimbatore, India.

\section{References}

Abdallh, M. N., W. S. Abdelhalim and H.S. Abdelhalim: Biological treatment of leather tanneries wastewater effluent-bench scale modeling. Int. J. Eng Sci., 9, 2272-2286 (2016).

Acosta, R. I., X. Rodriguez., C. Gutierrez and M.D.G. Moctezuma: Biosorption of chromium from aqueous solutions onto fungal biomass. Bioinorg. Chem. App., 2, 1-7 (2004).

Ahluwalia, S.S. : Microbial removal of hexavalent chromium and scale up potential. Int. J. Curr. Microbiol. Appl. Sci., 3, 383-398 (2014).

Ahsan, N., S.H. Lee, D.G. Lee, H. Lee, S.W. Lee, J.D. Bahk and B.H. Lee: Physiological and protein profiles alternation of germinating rice seedlings exposed to acute cadmium toxicity. C.R. Biol., 330, 735746 (2007). 
Anastasi, A., F. Spina, V. Prigione, V. Tigini, P. Giansanti and G.C. Varese: Scale-up of a bioprocess for textile wastewater treatment using Bjerkandera adusta. Bioresour. Technol., 101, 3067-3075 (2010).

APHA: Standard Methods for Examination of Water and Wastewater. $22^{\text {nd }}$ Edn. APHA, AWWA, WPCF, Washington DC, USA(2012).

Arévalo-Rangel, D.L., J.F. Cárdenas-gonzalez, V. M Martínez-juárez and I. Acosta-rodríguez: Hexavalent chromate reductase activity in cell free extracts of Penicillium spp. Bioinorg. Chem. Appl., Article ID $909412(2013)$

Aslam, M. S., A. Aishy, Z.Q. Samra, I. Gull and M.A. Athar: Identification, purification and characterization of a novel extracellular laccase from Cladosporium cladosporioides. Biotechnol. Biotechnol. Equip., 26, 3345-3350 (2012).

Baccar, R., P. Blánquez, J. Bouzid, M. Feki, H. Attiya and M. Sarra: Decolourization of a tannery dye: From fungal screening to bioreactor application. Biochem. Eng. J., 56,184-189 (2011).

Bisht, J. and N.S.K. Harsh: Utilizing Aspergillus niger for bioremediation of tannery effluent. Oct. J. Env. Res., 2, 77-81 (2014).

Bonugli-Santos, R. C., L.R. Durrant and L.D. Sette: The production of ligninolytic enzymes by marine-derived basidiomycetes and their biotechnological potential in the biodegradation of recalcitrant pollutants and the treatment of textile effluents. Water Air Soil Pollut., 223, 2333-2345 (2012).

Bourbonnais, R., M. G. Paice, I. D. Reid, P. Lanthier and M. Yaguchi: Lignin oxidation by laccase isozymes from Trametes versicolor and role of the mediator 2, 2'-azinobis (3-ethylbenzthiazoline-6sulfonate) in kraft lignin depolymerization. Appl. Environ. Microbiol., 61, 1876-1880 (1995).

Brijwani, K., A. Rigdon and V. Vadlani: Fungal laccases: Production, function, and applications in food processing. Enzyme Res., Article ID 149748, (2010).

Choi, Y. S., J. Y. Seo, H. Lee, J. Yoo, J. Jung, J. J. Kim and G. H. Kim Decolorization and detoxification of wastewater containing industrial dyes by Bjerkandera adusta KUC9065. Water Air Soil Pollut., 225, 1801 (2014).

Chowdhury, M., M. G. Mostafa, T. K. Biswas, A. Mandal and A.K. Saha: Characterization of the effluents from leather processing industries. Environ. Processes., 2, 173-187 (2015).

Chopra, A. K. and P. P. Singh: Removal of color, COD and lignin from pulp and paper mill effluent by Phanerochaete chrysosporium and Aspergillus fumigatus. J. Chem. Pharm. Res., 4, 4522-4532(2012).

Dhakar, K. and A. Pandey: Extracellular laccase from a newly isolated psychrotolerant strain of Cladosporium tenuissimum (NFCC 2608). Proceedings of the National Academy of Sciences, India Section B: Biol. Sci., 86, 685-690 (2016).

El-Kassas, H.Y. and E.M. El-Taher: Optimization of batch process parameters by response surface methodology for mycoremediation of Chrome-VI by a chromium resistant strain of marine Trichoderma viridae. American-Eurasian J. Agric. Environ. Sci., 5, 676-681 (2009).

Fakhru'l-Razi, A. and A.H. Molla: Enhancement of bioseparation and dewaterability of domestic wastewater sludge by fungal treated dewatered sludge. J. Hazard. Mater., 147, 350-356 (2007).

Gochev, V. K., Z.I. Velkova and M.S. Stoytcheva: Hexavalent chromium removal by waste mycelium of Aspergillus awamori. J. Serb. Chem. So., 75, 551-564 (2010).

Gomez-Bertel, S., D. Amaya-Bulla, C. Maldonado-Saavedra, M.M.Martinez-Salgado, B. Quevedo-Hidalgo, A. B. Soto-Guzman and A.M. Pedroza-Rodríguez: Evaluation of three lignolytic fungi and Aspergillus niger as an alternative for the treatment of wastewater from leather tanning. Int. J. Environ. Pollut., 24, 93-106 (2008).
Hall, T. A.: BioEdit: A user friendly biological sequence alignment editor and analysis program for windows 95/98/NT. Nucleic Acids symposium, Oxford University Press, 41, pp. 95-98 (1999).

Hasegawa, M. C., A.M Barbosa and K. Takashima: Biotreatment of industrial tannery wastewater using Botryosphaeria rhodina. J. Serb. Chem. Soc., 76, 439-446 (2011).

Higgins, D. G., J.D. Thompson and T.J. Gibson: Using CLUSTAL for multiple sequence alignments. Methods Enzymol., 266, 383-402 (1996).

Hossain, K. and N. Ismail: Bioremediation and detoxification of pulp and paper mill effluent: A review. Res. J. Environ. Toxicol., 9, 113-134 (2015).

Hossain, K., S. Quaik, N. Ismail, M. Rafatullah, M. Avasan and R. Shaik: Bioremediation and detoxification of the textile wastewater with membrane bioreactor using the white-rot fungus and reuse of wastewater. Iranian J. Biotechnol., 14, 154 (2016).

Igwe, J. and A.A.A. Abia: Bioseparation process for removing heavy metals from wastewater using biosorbents. Afr. J. Biotechnol., 5, $1167-1179(2006)$

Jin, R., H. Liao, X. Liu, M. Zheng, X. Xiong, X. Liu, L. Zhang and Y. Zhu: Identification and characterization of a fungal strain with lignin and cellulose hydrolysis activities. Afr. J. Microbiol. Res., 6, 6545-6550 (2012).

Jnr, M.H. and A.I. Spiff: Effects of temperature on the sorption of $\mathrm{Pb}^{2+}$ and $\mathrm{Cd}^{2+}$ from aqueous solution by Caladium bicolor (wild cocoyam) biomass. Electronic J. Biotechnol., 8, 43-50 (2005).

Ko, S. S., R.K. Kunimoto and W.H. Ko: A simple technique for purifying fungal cultures contaminated with bacteria and mites. J. Phytopathol., 149, 509-510 (2001).

Kongjao, S., S. Damronglerd and M. Hunsom: Simultaneous removal of organic and inorganic pollutants in tannery wastewater using electrocoagulation technique. Korean J. Chem. Eng., 25, 703-709 (2008).

Kunjadia, P. D., G.V Sanghvi, A.P. Kunjadia, P.N. Mukhopadhyay and G.S. Dave: Role of ligninolytic enzymes of white rot fungi (Pleurotus spp.) grown with azo dyes. SpringerPlus, 5, 1487 (2016).

Mabrouk, M. A., Z. H. Kheiralla, E.R. Hamed, A. A. Youssry and A.A. Abd El Aty: Screening of some marine-derived fungal isolates for lignin degrading enzymes (LDEs) production. Agric. Biol. J. North America, 1, 591-599 (2010).

Madhavi, V. and S.S. Lele: Laccase: Properties and applications. BioResource, 4, 1694-1717 (2009).

Mehta, A. and N. Bhardwaj: Phytotoxic effect of industrial effluents on seed germination and seedling growth of Vigna radiata and Cicer arietinum. Global J. Bio-sci. Biotech, 1, 1-5 (2012).

Nikazar, M., L. Davarpanah and F. Vahabzadeh: Biosorption of aqueous chromium (VI) by living mycelium of Phanerochaete chrysosporium. Chem. Eng. Trans, 14, 475-480 (2008).

Noorjahan, C. M. and S. A. Siddiqui: Biodegradation of tannery effluent, its reuse in agriculture and biochemical characterization by electrophoresis. Int. J. Cur. Res. Rev.,9, 8-14 (2017).

Ravikumar, R., N.S. Vasanthi and K. Saravanan: Single factorial experimental design for decolurising anaerobically treated distillery spent wash using Cladosporium cladosporioides. Int. J. Environ. Sci. Technol., 8, 97-106 (2011).

Saranraj, P. and D. Sujitha: Microbial bioremediation of chromium in tannery effluent. A Review. Int. J. Microbiol. Res., 4, 305-320 (2013).

Sharma, S. and P. Malaviya: Bioremediation of tannery wastewater by chromium resistant fungal isolate Fusarium chlamydosporium SPFS2-g. Curr. World Environ., 9, 721 (2014).

Sharma, S. and P. Malaviya: Bioremediation of tannery wastewater by Aspergillus flavus SPFT2. Int. J. Curr. Microbiol. Appl. Sci., 5, 137$143(2016)$.

Sharma, S. and P. Malaviya:Decolorization and detoxification of tannery 
wastewater by Trichoderma virideSPFT1. Environ. Eng. Manag. J.,17,545-550 (2018)

Shoaib, A., N. Aslam and N. Aslam: Trichoderma harzianum :Adsorption, desorption, isotherm and FTIR studies. J. Anim. Plant. Sci., 23, 1460-1465 (2013).

Srikanlayanukul, M., C. Khanongnuch and S. Lumyong: Decolorization of textile wastewater by immobilized Coriolus versicolor RC3 in repeated-batch system with the effect of sugar addition. CMU. J., 5, 301 (2006).

Srivastava, S. and I.S. Thakur: Evaluation of bioremediation and detoxification potentiality of Aspergillus niger for removal of hexavalent chromium in soil microcosm. Soil Biol. Biochem., 38,
1904-1911 (2006)

Sundaramoorthy, P. and J. Kunjithapatham: Effect of paper mill effluent on seed germination and seedling growth of six varieties of groundnut (Arachis hypogaea). J. Ecotoxicol. Environ Monit., 10, 53-57 (2000).

Tapia-Tussell, R., D. Pérez-Brito, R. Rojas-Herrera, A. CortesVelazquez, G. Rivera-Muñoz and S. Solis-Pereira: New laccaseproducing fungi isolates with biotechnological potential in dye decolorization. Afr. J. Biotechnol., 10, 10134-10142 (2011).

Tehrani, M. M., M.M. Assadi and H. Rashedi: Biodecolorization of textile effluents by autochthonous fungi. J. Appli. Biotechnol Rep., 1, 161$165(2015)$. 